\title{
OPTIMALISASI PERAN GURU DALAM PROSES TRANSFORMASI PENGETAHUAN DENGAN MENGGUNAKAN MEDIA PEMBELAJARAN
}

\author{
Oleh: Muhammad Rusydi Rasyid*
}

\begin{abstract}
The traditional blackboard is really very much like a computer screen. It can be used to explain ideas graphically, with text and numbers, and can be used by the students like an interactive interface in a computer. The use of films, videotapes, audiotapes, records, and even performance can enhance the learning process in the classroom. The technique of using media requires creativity and planning. What media are available? How many of them should be used? Do media have psychological effect to students? What is the proper role for teaching with media? Media in the classroom are appropriate for triggering ideas, making difficult subjects more understandable, and for holding attention on important ideas. They should lead students to remember ideas by becoming more involved with them.
\end{abstract}

KEYWORDS: Guru, media, teknologi, individual differences

ADA dua paradigma yang berkembang dalam proses belajar mengajar atau lebih dikenal dengan istilah proses transformasi pengetahuan antara guru dan siswa, meskipun salah satunya adalah old fashion, yaitu teacher center dan student center. ${ }^{1}$

Pada era 70-an dan sebelumnya, Kevin Barry dan Len King menulis seputar eksistensi pandangan teacher center yang sudah menjadi great paradigm dan berkembang di alam bawah sadar para guru dan siswa. Pandangan ini menjelaskan bahwa semua informasi, main resources-nya berasal dari guru. Guru dianggap sebagai master of knowing - tuan segala tahu. Dialah yang menjadi nakoda dari lalu lintas semua informasi. Ada kesan, siswa tidak mampu memberikan ide-ide cemerlang atau argumen baru yang mendahului master of knowing. Harapan agar siswa bisa

*Magister dalam bidang Pendidikan Islam ini adalah lulusan Program Pascasarjana IAIN Alauddin Makassar tahun 2001. Ia meraih magister kedua kalinya pada Faculty of Eduation Curtin University of Technology Western Australia tahun 2004. Dosen Fakultas Tarbiyah dan Keguruan UIN Alauddin ini sedang menjabat sebagai Sekretaris Project Management Unit of UIN Alauddin of Islamic Development Bank (PMU-IDB). 
melakukan critical analysis apalagi untuk berimprovisasi sangatlah jauh. Siswa merasa segan bahkan tidak ada keinginan untuk menambah pengetahuan baru yang mungkin saja bisa diperoleh dari berbagai media, seperti: alam, informasi, atau sumber-sumber lain di sekitarnya yang 'mungkin' erat kaitannya dengan materi yang diterima di sekolahnya. Siswa akan menganggap dirinya 'kualat' jika ia berposisi lebih tahu atau mendapatkan informasi pengetahuan lebih dahulu dari 'sang guru'. ${ }^{2}$ Demikian pula, seorang guru sudah 'menikmati' dan berkreasi dengan pandangan tersebut, dia tidak mempunyai keinginan agar siswanya maju apalagi kalau dikatakan siswa tersebut lebih cerdas dari gurunya, karena hal itu adalah 'aib' di hadapan siswa dan di kalangan masyarakat umum. ${ }^{3}$ Ia akan merasa senang jika materinya dianggap sukar, hanya dia yang tahu dan hanya dia yang bisa mengajarkannya. Apa yang diketahui oleh sumbernya berasal dari guru, siswa juga tidak berani menyampaikan informasi yang kemungkinan lebih dahulu didapatkannya.

Sebaliknya, untuk student center, di antara fungsi utama seorang guru di dalam kelas adalah sebagai fasilitator. Guru lebih sering memandu siswa untuk melakukan aktivitas belajar sehingga informasi itu bisa berjalan dari dua arah, mungkin informasi itu dari guru dan mungkin juga informasi baru itu berasal dari siswa, sehingga benar-benar terjadi proses take and give. Tidak hanya pengetahuan atau informasi guru bisa sama dengan siswanya, bahkan siswa tersebut bisa lebih dulu tahu dari gurunya. Karena perkembangan teknologi dan informasi yang sangat pesat sekarang, guru bukan lagi satu-satunya sumber belajar (learning resource). Siswa bisa mendapatkan informasi lebih dahulu melalui media seperti koran, TV, bahkan melaui world wide web (internet). Seorang pengajar yang baik harus menyikapi hal ini secara positif. Sang pengajar harus berusaha cepat menyesuaikan diri dengan jalan mengakses informasi sebanyak-banyaknya serta selalu melakukan up date informasi dan pengetahuan yang terkait dengan bidang dan keahliannya.

Sejalan dengan perubahan kurikulum dan desentralisasi pendidikan, maka bukan lagi eranya bagi seorang pengajar untuk selalu menunggu petunjuk dari atasan (kepala sekolah, pengawas, dan seterusnya). Ia harus proaktif mencari, berimprovisasi, dan melakukan inovasi baik pada saat merancang KBM maupun pada saat melakukan proses transformasi pengetahun di dalam kelas. Guru perlu segera mereposisi perannya. Pada saat ini, guru tidak lagi harus menjadi orang yang the only one knows atau menjadi one man show di kelas. Namun, ia harus sanggup menjadi fasilitator belajar yang mampu menerapkan berbagai macam metode dan strategi pada saat mengajar. ${ }^{4}$ Siswa diberikan kesempatan untuk terlibat langsung 
secara penuh pada saat proses pembelajaran berlangsung. Ada banyak sumber belajar yang tersedia di lingkungan, apakah sumber belajar yang dirancang untuk belajar atau yang tidak dirancang, tetapi dapat dimanfaatkan untuk belajar. Guru yang baik akan merasa senang kalau muridnya lebih pandai dari dirinya. ${ }^{5}$

Seorang pengajar yang profesional selalu berusaha mencari cara yang terbaik untuk mencapai sasaran pembelajaran. Ia akan menggunakan berbagai macam media pembelajaran-mulai dari media yang berbasis manusia, cetak, audio visual sampai kepada komputer-dalam rangka membantu siswa untuk mencerna materi pelajaran lebih cepat dan efisien. ${ }^{6}$

Dengan menggunakan media, materi yang semestinya harus dicapai dalam waktu 2 jam pelajaran dapat disingkat menjadi 1 jam pelajaran sehingga pengayaan materi kepada peserta didik bisa lebih ditingkatkan, bahkan dengan kemampuan guru menggunakan media pembelajaran, ia mampu membawa siswa kepada tingkat analisis dan eksplorasi terhadap setiap materi pelajaran.

Tulisan ini berusaha membahas bagaimana peran guru sebagai fasilitator dan media sebagai sarana percepatan penyampaian informasi serta peran psikologis yang menjadi sisi lain dari kedua aspek tersebut.

\section{GURU DAN MEDIA PEMBELAJARAN}

Dalam sistem pengajaran modern, keterlibatan guru mulai dari perencanaan, inovasi pendidikan sampai kepada pelaksanaan dan evaluasinya memainkan peran yang sangat besar bagi keberhasilan suatu pengajaran. Guru di sekolah mempunyai peran yang luas sebagai pendidik, orangtua, teman, dokter, motivator, dan lain sebagainya. ${ }^{7}$

Namun demikian, ada hal yang tidak bisa diabaikan dalam proses pendidikan khususnya dalam proses belajar mengajar, yaitu fasilitas yang merupakan bahagian yang ikut mempengaruhi hasil dari proses pembelajaran. Tanpa adanya fasilitas, maka proses improvisasi pendidikan yang dilakukan oleh guru tidak berjalan dengan baik. Fasilitas, terutama fasilitas belajar mengajar, merupakan hal yang esensial dalam mengadakan pembaruan dan inovasi pendidikan, seperti ketersediaan gedung sekolah, bang$\mathrm{ku}$, meja, dan alat bantu mengajar (radio, TV, OHP, LCD, pana board, handycam, video-DVD, dan lain-lain). Terkait dengan proses pembelajaran, ada baiknya jika dalam tulisan ini dikaitkan dengan pembahasan tentang belajar yang dilakoni oleh siswa dan guru sebagai fasilitatornya.

Belajar merupakan aktivitas interaksi yang kompleks antara individu terhadap lingkungannya yang terjadi sepanjang hayatnya, kapan saja, dan di mana saja. ${ }^{8}$ 
Proses pembelajaran yang terjadi di sekolah (pendidikan formal) bertujuan membawa perubahan kepada anak didik yang terjadi secara sistematis dan terpogram untuk mengembangkan aspek kognitif, afektif, dan psikomotorik dari anak didik. Proses interaksi belajar siswa dipengaruhi oleh banyak elemen di antaranya para siswa yang ada di sekitarnya, guru, kepala sekolah, materi ajar, serta media atau sumber belajar yang digunakan. Kemajuan teknologi dan informasi mengharuskan adanya upaya pembaruan dalam pemanfaatan teknologi belajar. ${ }^{9}$ Guru dituntut mampu menggunakan instrumen-instrumen yang disediakan oleh sekolah atau lembaga dalam rangka mempercepat proses transformasi pengetahuan. Guru juga diharapkan mampu melakukan improvisasi metode dan strategi dalam proses pembelajaran. Kendala-kendala yang dihadapi guru di dalam kelas dapat diatasi jika guru tersebut mampu berimprovisasi termasuk melakukan eksplorasi media pembelajaran yang berdaya guna. Seorang pengajar dapat menyelami dan mengerti class room climate yang dihadapi, sehingga ia mampu mendesain alat belajar yang dapat memacu motivasi siswa dalam belajar. Bahkan, siswa akan merasa tidak nyaman jika tidak berkonsentarasi terhadap materi yang dijelaskan oleh gurunya.

Oleh karena itu, guru yang baik yang menghendaki anak didiknya dapat mencerna materi yang diajarkan secara maksimal akan berusaha (di samping mengandalkan penguasaan sejumlah materi dan metode) menggunakan alat bantu (media pengajaran). Hal ini dilandasi prinsip bahwa kemampuan guru menyampaikan pelajaran mempunyai keterbatasan terutama kemampuan mengartikulasikan materi-materi dalam bentuk verbal. ${ }^{10}$ Oleh karena itu, guru berusaha menggunakan media sebagai alat bantu sekaligus partner yang mempercepat proses transfer materi yang diajarkannya.

Beberapa kesulitan akan dihadapi oleh guru pada saat mengajar jika tidak menggunakan media pengajaran, terutama jika guru tersebut ingin anak didiknya terlibat langsung secara emosional dalam materi yang diajarkan. Misalnya, guru ingin menjelaskan peristiwa sejarah yang terjadi pada masa lampau, tentu saja ia tidak akan mampu membawa siswa ke era tersebut, tetapi dengan bantuan media, ia dapat memperlihatkan bagaimana kronologis dari sebuah peristiwa sejarah. Contoh lain, mungkin seorang pengajar pernah menghadapi kesulitan dalam menjelaskan suatu meteri pelajaran kepada murid, misalnya, menjelaskan tentang seekor binatang yang disebut gajah kepada siswa SD kelas satu-dua awal, atau seorang pengajar ingin menjelaskan tentang kereta api kepada murid yang berada di Kalimantan, Irian, atau di tempat lain yang tidak ada kereta api, atau ingin menjelaskan tentang apa itu pasar terapung. Ada beberapa cara 
yang mungkin dilakukan guna membantu metode ceramah dalam menyampaikan informasi tersebut.

Pertama, guru akan bercerita tentang gajah, kereta api, atau pasar terapung. Guru tersebut mampu bercerita mungkin karena pengalaman, membaca buku, cerita orang lain, atau pernah melihat gambar ketiga obyek itu. Apabila murid yang diajar tersebut sama sekali belum tahu, belum pernah melihat dari televisi atau gambar di buku misalnya, maka betapa sulitnya guru menjelaskan hanya dengan berbekal untaian kata demi kata tentang obyek tersebut. Jika pengajar mempunyai kemampuan mendeskripsikan sebuah cerita sehingga terkesan kisah tersebut seakan-akan hidup, seakan-akan berinteraksi dalam lakon cerita tersebut, maka akan sangat menarik bagi murid-murid. ${ }^{11}$ Akan tetapi, tidak semua orang diberikan karunia kepandaian bercerita. Penjelasan dengan kata-kata mungkin akan menghabiskan waktu yang lama, pemahaman murid juga berbeda sesuai dengan pengetahuan mereka sebelumnya, bahkan bukan tidak mungkin akan menimbulkan kesalahan persepsi.

Kedua, membawa murid untuk studi wisata melihat objek tersebut. Cara ini merupakan yang paling efektif dibandingkan dengan cara lainnya. Namun, berapa biaya yang harus ditanggung dan berapa lama waktu diperlukan. ${ }^{12}$ Cara ini walaupun efektif, tetapi tidak efisien. Tidak mungkin dipaksakan bahwa dalam belajar semua siswa harus mempunyai pengalaman yang sama atau mengalami segala sesuatu yang sama dengan temannya yang lain.

Ketiga, membawa gambar, foto, film, video tentang objek tersebut. Cara ini akan sangat membantu guru dalam memberikan penjelasan. Selain menghemat kata-kata, menghemat waktu, penjelasan akan lebih mudah dimengerti oleh murid, menarik, membangkitkan motivasi belajar, menghilangkan kesalahan pemahaman, serta informasi yang disampaikan menjadi konsisten.

Ketiga cara di atas dapat disebutkan bahwa cara pertama sebagai informasi verbal, cara kedua berupa pengalaman nyata, sedangkan cara ketiga berupa informasi melalui media. Di antara ketiga cara tersebut, cara ketiga adalah cara yang paling bijaksana dilakukan. Media diperlukan agar pembelajaran lebih efektif dan efisien. Menurut Azhar Arsyad,13 ada beberapa manfaat penting yang harus diketahui oleh guru karena menggunakan media, yaitu:

1. Media pembelajaran dapat memperjelas penyajian materi dan informasi sehingga dapat memperlacar proses belajar mengajar.

2. Media pembelajaran dapat mengatasi keterbatasan indera, ruang, dan waktu. Misalnya mengajarkan gajah kepada peserta didik tidak diperlu- 
kan mendatangkan gajah tersebut ke ruang kelas, tetapi cukup dengan memperlihatkan gambarnya.

3. Media dapat memberikan kesamaan pengalaman kepada siswa tentang berbagai peristiwa di lingkungan mereka serta memungkinkan terjadinya interaksi langsung dengan guru dan masyarakat.

4. Pelajaran akan lebih jelas maknanya dan tujuannya sehingga siswa mudah memahaminya.

5. Metode mengajar akan lebih beragam, tidak semata-mata hanya mengandalkan komunikasi verbal, sehingga siswa tidak merasa bosan dengan kegiatan belajar mengajar tersebut.

Di era percaturan global, era yang ditandai dengan roda perkembangan teknologi dan informasi yang susul-menyusul secara estafet dengan sangat cepat dan signifikan, maka penemuan-penemuan yang mengarah kepada perkembangan teknologi pembelajaran menuntut sekolah, guru, dan semua stake holder berusaha memenuhi tuntutan perkembangan pengajaran yang mencakup materi, metode, dan medianya. Sebab, media dalam bentuk hard ware maupun soft ware memegang peranan penting dalam proses percepatan transfomasi pengetahuan antara guru dan siswa serta informasi itu sendiri. ${ }^{14}$

Dengan menggunakan media, pengajar mampu mengakselerasi meteri yang diajarkan kepada siswa. Walaupun begitu, masih ada guru yang enggan menggunakan media pembelajaran dengan beberapa pertimbangan. Berikut ini dikemukakan pertimbangan-pertimbangan mengapa guru tersebut belum rela menggunakan media, juga sekaligus counter dari apologi tersebut.

Pertama, menggunakan media itu repot. Mengajar dengan menggunakan media perlu persiapan yang matang, bahkan di rumah harus mempelajari manual instruction-nya, terutama jika media tersebut seperti OHP (Over Head Projector), Liqiud Cristal Display (LCD) atau video, yang memerlukan listrik dan keterampilan tersendiri dalam menggunakannya. ${ }^{15}$ Menulis persiapan mengajar dengan menggunakan alat tersebut memerlukan waktu yang panjang sementara banyak kegiatan lain di rumah. Padahal, kalau seorang guru sedikit saja mau berpikir dari aspek lain, bahwa dengan menggunakan media pembelajaran, materi yang disampaikan akan lebih efektif dan efisien, maka alasan repot itu akan hilang. Harus dicamkan oleh guru bahwa dengan sedikit repot, tetapi mendapatkan hasil optimal, perasaan terbebani dengan setumpuk alasan, yang mungkin saja kurang rasional, dapat teratasi. Hal in logis, karena tanggung jawab guru adalah berusaha mencari cara, metode, pendekatan yang inovatif untuk mengantar siswa ke gerbang pengertian dan perubahan sikap setelah mengetahui dan mencapai tujuan pembelajaran. Demikian pula, pema- 
kaian media relatif awet, sekali menyiapkan materi dapat digunakan beberapa kali sajian, sehingga dapat membantu guru untuk mengurangi kerepotam penyiapan media sekaligus materi belajar.

Kedua, media itu canggih dan memerlukan biaya yang besar untuk mengadakannya. Tidak selamanya media itu harus menggunakan latest technology dan mahal. Nilai dari sebuah media tidak diukur dengan kecanggihan teknologinya, apalagi harganya yang mahal, tetapi terletak pada efektivitas dan efisiensinya dalam membantu proses pembelajaran serta kecakapan guru mengoperasikannya dan memanipulasi media tersebut. Sebenarnya, banyak media sederhana dapat dikembangkan sendiri oleh guru dengan harga yanng relatif murah. Kalaupun dibutuhkan media canggih semacam audio visual atau multimedia, biayanya akan menjadi murah apabila dapat digunakan oleh lebih banyak siswa dan banyak kelas.

Ketiga, tidak bisa. Demam teknologi ternyata menyerang sebagian guru. Ada beberapa guru yang 'takut' dengan peralatan elektronik, takut kesetrum, dan takut salah pencet. Alasan ini menjadi lebih parah kalau ditambah dengan takut rusak, sehingga media audio visual sejak dibeli pertama kali, kondisinya akan tetap sama sampai beberapa tahun kemudian-terbungkus dengan karet busa-sehingga barang tersebut tetap baru dan tersimpan rapih di ruang kepala sekolah. Sebenarnya, dengan sedikit latihan dan mengubah sikap bahwa media itu mudah dan menyenangkan, maka segala sesuatunya akan berjalan dengan lancar.

Keempat, media itu hiburan sedangkan belajar itu serius. Alasan ini jarang ditemui, tetapi ada. Menurut paradigma dulu, belajar itu harus serius. Belajar harus mengerutkan dahi, konsentrasi penuh. Media itu identik dengan hiburan. Hiburan adalah hal yang berbeda dengan belajar. Tidak mungkin belajar sambil santai. Paradigma belajar kini sudah berubah. Kalau bisa dilakukan dengan menyenangkan, mengapa harus dipersulit.

Kelima, tidak tersedia. Tidak tersedia media di sekolah, mungkin ini adalah alasan yang masuk akal. Akan tetapi, seorang guru tidak boleh menyerah begitu saja. Ia adalah seorang profesional yang harus penuh inisiatif. Seperti telah disebutkan di atas, media tidak harus selalu canggih, tetapi dapat juga dikembangkan sendiri oleh guru. Walaupun begitu, dalam hal ini pimpinan sekolah juga hendaklah cepat tanggap. Jangan dibiarkan suasana kelas itu gersang, hanya ada papan tulis dan kapur.

Keenam, kebiasaan menikmati bicara. Berbicara itu memang nikmat. Ini kebiasaan yang sulit diubah. Seorang guru cenderung mengikuti cara gurunya dahulu. Mengajar dengan mengandalkan verbal lebih mudah, tidak memerlukan persiapan yang banyak, jadi lebih enak untuk guru. 
Namun, yang harus dipertimbangkan dalam proses pembelajaran adalah kepentingan murid yang belajar, bukan kepuasan guru semata. ${ }^{16}$

\section{KRITERIA MEMILIH MEDIA PEMBELAJARAN}

Media merupakan perangkat lunak atau alat yang digunakan oleh pengajar dalam rangka membantu mempercepat proses penyajian materi yang disampaikan di dalam kelas. Media, jika dilihat dari aspek pengadaannya, terdiri dari dua bahagian, yaitu: media jadi yang merupakan komoditi perdagangan yang terdapat di pasaran dalam keadaan ready to use, dan media rancangan yang harus dirancang dan didesain secara khusus untuk keperluan pembelajaran tertentu. Kelebihan dari media jadi, hemat biaya pengadaan, waktu, tenaga dan cenderung tidak merepotkan, bagi mereka yang mengerti teknologinya. Untuk pengoperasiannya cukup membaca manual dan mengikuti langkah-langkah yang tertuang dalam manual book dari media tersebut. Kekurangan dari media ini adalah kendala yang dihadapi pada saat menyesuaikan materi pelajaran yang belum tentu pas dengan media tersebut. Misalnya, siswa yang ingin belajar writing, tetapi media yang tesedia hanya tape recorder, maka seorang guru harus pandai menyesuaikan media yang ada. Sementara, media yang didesain secara khusus untuk kebutuhan pengajaran tertentu membutuhkan tenaga ekstra, waktu yang harus diluangkan secara khusus, bahkan jumlah biaya yang agak besar karena dibutuhkan serangkain kegiatan validitas prototipenya.

Oleh karena itu, ada sejumlah kriteria yang mesti dilakukan oleh guru dalam memilih media pembelajaran yang tepat agar sesuai dengan tujuan yang hendak dicapai dan situasi yang tidak memungkinkan penggunaan suatu media serta keterbatasan penggunaannya dapat diminimalisasi. Berbagai pertimbangan tersebut di antaranya:

Pertama, kemudahan akses menjadi pertimbangan pertama dalam memilih media. Apakah media yang diperlukan itu tersedia, mudah, dan dapat dimanfaatkan oleh murid? Misalnya, guru ingin menggunakan media internet, perlu dipertimbangkan terlebih dahulu apakah ada saluran untuk koneksi ke internet? Akses juga menyangkut aspek kebijakan, misalnya apakah murid diizinkan untuk menggunakannya? Komputer yang terhubung ke internet jangan hanya digunakan untuk kepala sekolah, tetapi juga guru, dan yang lebih penting untuk murid. Murid harus memperoleh akses yang equal terkait dengan penggunaan sarana yang ada di sekolah atau lembaga.

Kedua, banyak jenis media yang dapat menjadi pilihan bagi guru. Media canggih biasanya mahal. Namun, mahalnya biaya itu harus 
dihitung dengan aspek manfaatnya. Semakin banyak yang menggunakan, maka unit cost dari sebuah media akan semakin menurun. Oleh karena itu, biaya juga harus dipertimbangkan untuk mengukur kemampuan pengadaannya.

Ketiga, mungkin saja guru tertarik kepada satu media tertentu. Akan tetapi, guru perlu memperhatikan apakah teknologinya tersedia dan mudah menggunakannya? ${ }^{17}$ Katakanlah guru ingin menggunakan media audio visual di kelas, maka perlu mempertimbangkan, apakah ada listrik, voltase listrik cukup dan sesuai?

Keempat, media yang baik adalah yang dapat memunculkan komunikasi dua arah atau interaktivitas. Setiap kegiatan pembelajaran yang dikembangkan guru, tentu saja memerlukan media yang sesuai dengan tujuan pembelajaran tersebut.

Kelima, pertimbangan yang juga penting adalah dukungan organisasi. Misalnya, apakah pimpinan sekolah atau yayasan mendukung? Bagaimana pengorganisasiannya? Dan apakah di sekolah ini tersedia satu unit yang disebut pusat sumber belajar?

\section{ASPEK PSIKOLOGIS PENGGUNAAN MEDIA PEMBELAJARAN}

Guru sebagai ujung tombak dalam pelaksanaan pendidikan merupakan pihak yang sangat berpengaruh dalam proses belajar mengajar. Kepiawaian dan kewibawaan guru sangat menentukan kelangsungan proses belajar mengajar di kelas maupun efeknya di luar kelas. Guru harus pandai membawa siswanya kepada tujuan yang hendak dicapai.

Ada ungkapan yang mengatakan "mengajar itu adalah seni". Ungkapan tersebut tidaklah berlebihan karena seorang pengajar harus memilki keterampilian tersendiri dalam mentransfer materi pelajaran. Seorang guru harus menyatukan antara kemampuan mengartikulasikan informasi kepada siswa serta mimik yang ditampilkan di hadapan siswa sebagai tanda keseriusan manyampaikan materi, tetapi ini bukan berarti guru dapat melakoni kepura-puraan di hadapan siswa. Diakui bahwa dalam mengajar dibutuhkan kesabaran dan ketelatenan, karena yang akan diberi pengetahuan-pengalaman baru-adalah orang yang mempunyai berbagai perbedaan yang unik dari setiap individu dan dinamika tersendiri, individual difference. 18 Oleh karena itu, proses receptive dari setiap siswa tidak sama. Tingkat penerimaannya terhadap materi bervariasi, ada yang kecepatannya-jika diibaratkan dengan speed kendaraan-80 km per jam ada pula yang $60 \mathrm{~km}$ per jam atau $40 \mathrm{~km}$ per jam, bahkan ada yang hanya kurang dari $10 \mathrm{~km}$ per jam. Seorang guru yang baik harus mempunyai cara 
dan trik tersendiri dalam menyampaikan materi pelajaran, dengan tetap memperhatikan aspek perbedaan kemampuan setiap anak. ${ }^{19}$

Contoh sederhana, seorang guru yang akan mengajar IPA dengan pokok bahasan rantai makanan dan jaring kehidupan dan subpokok bahasan tentang bagaimana tumbuhan berkembang biak. Seorang guru dapat saja bercerita panjang lebar tentang cara-cara perkembangbiakan tumbuhan, secara generative atau vegetative. Namun, hasilnya berbeda dengan kalau guru menunjukkan benda yang sebenarnya (bunga, buah, biji, daun, dan batang tumbuh-tumbuhan tertentu) atau guru menunjukkan gambar penampangnya. Jika mungkin guru meminta siswa untuk membaca sendiri buku IPA yang berisi pokok dan sub pokok bahasan tersebut atau melihat program film bingkai. Jika guru ingin menunjukkan proses perkembangbiakannya, guru dapat memakai film atau video. Itu semua akan lebih konkret daripada diceriterakan secara verbal semata.

Guru tidak selamanya membawa siswa ke objek sebenarnya, guru harus membawa benda sebenarnya ke siswa. Dapat dibayangkan, jika guru harus mengajarkan proses terjadinya gerhana bulan, maka guru perlu sumber lain untuk menyampaikan pesan tersebut seperti model, gambar, bagan, dan film yang bisa menyajkan pesan tersebut dengan baik. Di sini akan terlihat kemampuan siswa menerima materi tersebut akan berbedabeda. Ada yang menerima materi hampir $100 \%$, ada yang hanya $50 \%$, bahkan ada yang di bawah standar. Untuk menutupi kekurangan tersebut, guru dituntut untuk menggunakan media dalam rangka memaksimalkan kemajuan receptive siswa. Sebagai guru atau instruktur suatu latihan, harus diakui bahwa guru bukanlah satu-satunya sumber belajar. Istilah proses belajar mengajar hendaklah diartikan bahwa proses tersebut dalam diri siswa terjadi, baik karena ada yang secara langsung mengajar (guru, instruktur) maupun secara tidak langsung. Belajar tidak langsung artinya siswa aktif berinteraksi dengan media atau sumber belajar lainnya.

Proses belajar mengajar di kelas yang melibatkan guru dan siswa dengan menggunakan media pembelajaran, secara umum dapat memberikan pengaruh psikologis yang sangat signifikan, terutama dalam proses pemerolehan pengetahuan sesuai dengan tujuan yang diinginkan oleh pengajar.

Penggunaan media pendidikan secara tepat dan bervariasi dapat mengatasi sikap pasif peserta didik. Dalam hal ini media pendidikan secara psikologis dapat menimbulkan kegairahan belajar, sehingga memungkinkan peserta didik belajar sendiri-sendiri menuntut kemampuan dan minatnya.

Dengan sifat yang unik pada setiap siswa ditambah dengan lingkungan dan pengalaman yang berbeda, sedangkan kurikulum dan materi 
pendidikan ditentukan sama untuk setiap siswa, maka guru banyak mengalami kesulitan bilamana semuanya itu harus diatasi sendiri. Hal ini akan lebih sulit bila latar belakang lingkungan guru dengan siswa juga berbeda. Masalah ini dapat diatasi dengan media pendidikan, yaitu dengan kemampuannya dalam:

- memberikan perangsang yang sama;

- mempersamakan pengalaman;

- menimbulkan persepsi yang sama.

Oleh krena itu, seorang guru harus mempertimbangkan beberapa pengaruh atau aspek psikologis pada saat memutuskan untuk menggunakan media tertentu, di antara pertimbangan tersebut adalah:

\section{Motivasi}

Harus ada kebutuhan, minat, atau keinginan untuk belajar dari pihak siswa sebelum meminta perhatiannya untuk mengerjakan tugas dan latihan. Lagi pula, pengalaman yang akan dialami siswa harus relevan dengan dan bermakna baginya. Oleh karena itu, penggunaan media dapat memberi stimulus kepada siswa agar mereka tergugah keinginannya untuk belajar dan lebih concern terhadap materi yang diajarkan oleh guru.

\section{Individual Difference}

Siswa belajar dengan cara dan tingkat kecepatan yang berbeda-beda. Faktor-faktor seperti kemampuan inteligensia, tingkat pendidikan, kepribadian, dan gaya belajar mempengaruhi kemampuan dan kesiapan siswa untuk belajar. Tingkatan kecepatan penyajian informasi melalui media harus berdasarkan kepada tingkat pemahaman.

\section{Emosi}

Pembelajaran yang mengakibatkan emosi dan perasaan pribadi serta kecakapan amat berpengaruh dan bertahan. Media pembelajaran adalah cara yang sangat baik untuk menghasilkan respons emosional seperti takut, cemas, empati, cinta kasih, dan kesenangan. ${ }^{20}$ Oleh karena itu, perhatian khusus harus ditujukan kepada elemen-elemen rancangan media jika hasil yang diinginkan berkaitan dengan pengatahuan dan sikap.

\section{Partisipasi}

Agar pembelajaran berlangsung dengan baik, seorang siswa harus menginternalisasi informasi, tidak sekadar diberitahukan kepadanya. Oleh sebab itu, belajar memerlukan kegiatan. Partisipasi aktif oleh siswa jauh lebih baik daripada mendengarkan dan menonton secara pasif. Partisipasi artinya kegiatan mental atau fisik yang terjadi di sela-sela penyajian materi 
pelajaran. Dengan partisipasi, kesempatan lebih besar terbuka bagi siswa untuk memahami dan mengingat materi pelajaran itu. ${ }^{21}$

\section{Penguatan (Reinforcement)}

Apabila siswa berhasil belajar, ia didorong untuk terus belajar. Pembelajaran didorong oleh keberhasilan amat bermanfaat, dapat membangun kepercayaan diri, dan secara positif mempengaruhi perilaku di masa-masa yang akan datang.

\section{PENUTUP}

Tidak diragukan lagi bahwa media itu perlu dalam pembelajaran. Kalau sampai hari ini masih ada yang belum menggunakan media, itu hanya perlu sedikit perubahan sikap. Dalam memilih media, perlu disesuaikan dengan kebutuhan, situasi, dan kondisi masing-masing. Media tidak lagi dipandang sebagai alat bantu belaka, tetapi lebih sebagai alat penyalur pesan dari pemberi pesan ke penerima pesan.

Media pendidikan sebagai salah satu sumber belajar yang dapat menyalurkan pesan sehingga membantu mengatasi berbagai kendala belajar dan mempunyai peran psikologis dalam mengakselerasi proses pembelajaran. Perbedaan learning style, minat, inteligensi, keterbatasan daya indera, atau hambatan jarak geografis, jarak waktu dan lain-lain dapat diatasi dengan menggunakan media pendidikan secara baik dan terarah.

Sebagai subyek utama dalam pendidikan terutama dalam proses belajar mengajar, peserta didik memegang peran yang sangat dominan. Dalam proses belajar mengajar, peserta didik dapat menentukan keberhasilan belajar melalui penggunaan inteligensia, daya motorik, pengalaman, kemauan, dan komitmen yang timbul dalam diri mereka tanpa ada paksaan. Hal ini bisa terjadi apabila siswa juga dilibatkan dalam proses inovasi pendidikan termasuk penyediaan media pembelajaran.

\section{CATATAN AKHIR:}

1. Bruce Joyce dan Marsha Weil, Models of Teaching, New Jersey: Prentice-Hall International, 1986, h. 35.

2. Kevin Barry dan Len King, Beginning Teaching, International Edition, New South Wales: Social Science Press, 2002, h. 476.

3. John Bigs dan Ros Tefler, The Process of Learning, cetakan kedua, Sydney: Prantice Hall, 1989, h. 407.

4. Thomas Good dan Jere E. Brophy, Looking in Classrooms, cetakan keenam, Boston: Allyn and Bacon, 2003, h. 165. 
5. Harmer J., How to Teach English, cetakan pertama, Harlow-England: Addison Wesley Longman, 1998, h. 271.

6. Azhar Arsyad, Media Pembelajaran, Jakarta: RajaGrafindo Persada, 2004, h. 74.

7. Wright T., Roles of Teachers and Learners, Oxford: Oxford University Press, 1987, h. 43.

8. Azhar Arsyad. Media Pembelajaran, h. 72.

9. Umar Tirtajaya dan La Sulo, Pengantar Pendidikan, Jakarta: Rineka Cipta, 2005, h. 242.

10. Susan Groundwater, dkk., Teahning Challenges and Dilemmas, New South Wales: Harcourt Brace, 1998, h. 54.

11. Kemp J. E., Designing Effective Instruction, New York: MacMillan Publisher, 1994, h. 97.

12. Arief Sadiman, dkk., Media Pendidikan: Pengertian, Pengembangan, dan Pemanfaatanya, Jakarta: RajaGrafindo Persada, 2007, h. 2.

13. Azhar Arsyad. 2004, Media Pembelajaran, h. 71.

14. Wen S., Future of The Media: Memahami Zaman Teknologi Informasi, Batam Centre: Lucky Publisher, 2003, h. 30.

15. Bobbi DePorter dan Mike Hernacki. Quantum Learning: Membiasakan Belajar Nyaman dan Menyenangkan, Bandung: KAIFA, 1999, h. 77.

16. Bruce Joyce dan Marsha Weil, Models of Teaching, h. 438.

17. Molenda H. R., Instructional Media and the New Technology of Instruction, Canada: John Wiley \& Son, 1982, h. 29.

18. Paul Eggen dan Don Kauchack, Educational Psychology: Classroom Connections, New York: Macmillan College, 1994, h. 180.

19. Anita Woolfolk, Educational Psychology, Boston: Allyn and Bacon, 2004, h. 296.

20. David Matsumo, Culture and Psychology People Around the World, Stamford: Wodsworth Thomson Learning, 2000, h. 301.

21. John W. Santrock, Psychology, International Edition, The United States: McGraw-Hill, 2000, h. 368.

\section{DAFTAR PUSTAKA:}

Arsyad, Azhar, Media Pembelajaran, cetakan kelima, Jakarta: RajaGrafindo Persada, 2004.

Barry, Kevin dan Len King, Beginning Teaching, International Edition, New South Wales: Social Science Press, 2002.

Bigs, John dan Ros Tefler, The Process of Learning, cetakan kedua, Sydney: Prantice Hall, 1989.

DePorter, Bobbi dan Mike Hernacki. Quantum Learning: Membiasakan Belajar Nyaman dan Menyenangkan, Bandung: KAIFA, 1999.

Eggen, Paul dan Don Kauchack, Educational Psychology: Classroom Connections, New York: Macmillan College, 1994.

Good, Thomas dan Jere E. Brophy, Looking in Classrooms, cetakan keenam, Boston: Allyn and Bacon, 2003. 
Groundwater, Susan, dkk., Teahning Challenges and Dilemmas, New South Wales: Harcourt Brace, 1998.

Harmer J., How to Teach English, cetakan pertama, Harlow-England: Addison Wesley Longman, 1998.

Joyce, Bruce dan Marsha Weil, Models of Teaching, New Jersey: Prentice-Hall International, 1986.

Kemp J. E., Designing Effective Instruction, New York: MacMillan Publisher, 1994.

Matsumo, David, Culture and Psychology People Around the World, Stamford: Wodsworth Thomson Learning, 2000.

Molenda H. R., Instructional Media and the New Technology of Instruction, Canada: John Wiley \& Son, 1982.

Sadiman, Arief, dkk., Media Pendidikan: Pengertian, Pengembangan, dan Pemanfaatanya, Jakarta: RajaGrafindo Persada, 2007.

Santrock, John W., Psychology, International Edition, The United States: McGrawHill, 2000.

Tirtajaya, Umar dan La Sulo, Pengantar Pendidikan, Jakarta: Rineka Cipta, 2005.

Wen S., Future of The Media: Memahami Zaman Teknologi Informasi, Batam Centre: Lucky Publisher, 2003.

Woolfolk, Anita, Educational Psychology, Boston: Allyn and Bacon, 2004.

Wright T., Roles of Teachers and Learners, Oxford: Oxford University Press, 1987. 